\title{
USASBE: United States Association for Small Business and Entrepreneurship 2017
}

STEVE CRAMER

University of North Carolina at Greensboro, United States

\section{About USASBE}

The United States Association for Small Business and Entrepreneurship (USASBE) bills itself as the "largest independent, professional, academic organization in the world dedicated to advancing the discipline of entrepreneurship." USASBE has about

United States Association for Small Business and Entrepreneurship 2017

Philadelphia, Pennsylvania

January 19 - 22, 2017

https://usasbe. site-ym.com/ 1,000 members.

\section{Nature of the USASBE Conference}

Around 500 business faculty, Ph.D. students, and vendors attended the USASBE annual conference in Philadelphia on January 19-22, 2017. The main conference ran from Thursday afternoon through Sunday, with pre-conferences on the Wednesday before. Early-bird registration was $\$ 675$ (full cost was $\$ 750$ ), making USASBE much more expensive than most library conferences. However, the fee covered breakfasts, lunches, and one year of membership in the association.

All USASBE programming was held in Loews Philadelphia Hotel on Market Street, between City Hall and Independence Mall. The conference provided an opening-night reception at the Drexel Academy of Natural Sciences. The Saturday-night dinner gala included circus acrobats performing in the hotel ballroom.

The conference offered eight types of programs:

- Competitive papers (short solo presentations on research, teaching, or program design, followed by discussion)

- Teaching cases (presentations of case studies used in the classroom)

- Developmental papers (roundtable feedback on research in progress)

- Competitive workshops (interactive panel discussions)

- Rocket workshops (short workshops)

- Experiential exercises (presentations of classroom exercises)

- Student pitches (featuring students from Philadelphia-area universities, with several rounds of voting on multiple days of the conference)

- Exhibitor sessions (mostly related to entrepreneurship educational software)

Steve Cramer is the business librarian at the University of North Carolina Greensboro and a Coleman Fellow of Entrepreneurship Education,smcramer@uncg.edu. 
This program diversity resulted in a complex conference schedule. Three or four shorter events like rocket workshops and teaching cases were usually bundled into 75-minute program slots. Competitive paper discussions were held concurrently at different tables in a large room. Most competitive workshops were 75 minutes long. The format resembled typical programming at library conferences - most were panel discussions.

Given these various types of programs, the conference call-for-papers submission process was rather complicated, with separate descriptions, guidelines, deadlines, and "track chairs" for each program type, and 10-page submission proposals for competitive workshops. Competitive papers, teaching cases, and developmental papers were published in the annual conference proceedings, several summaries of which appear below.

\section{Exhibits}

With tables in the main hallway of the conference floor, Sage, Emerald, Business Expert Press, and a few other publishers exhibited. Their representatives were editors and content recruiters, not sales staff. Business schools and creators of entrepreneurship educational software also exhibited.

\section{USASBE I ncoming President on Strategic Refocusing of the Association}

Incoming USASBE President Heidi Neck (Babson College) began the conference sessions on Friday morning with a discussion of USASBE strategic planning. She discussed how the mission of the association will refocus on "entrepreneurship education through bold teaching, scholarship, and practice." With mission creep an identified issue in USASBE, Neck asserted that the association needs to identify work unrelated to education that it should stop doing. Nostalgia for traditions will need to be resisted as USASBE staff works to focus on education and attract more members who are not business school faculty.

\section{Experiential Exercise: Using Comedy to Teach Creativity}

Jamey Darnell (University of South Florida Sarasota-Manatee) led a 40-minute discussion and workshop on team-based learning called "The Experiential Exercise about Nothing: Using Comedy to Teach Creativity." After watching a video of Jerry Seinfeld explaining his process of writing a comedy routine, Darnell had groups of participants work on a comedy routine based on the excuses students make about missing class. The exercise concluded with a discussion of connecting joke telling with entrepreneurship concepts.

\section{Experiential Exercise: Using Music to Teach Theory}

The second session in this time block featured Emma Fleck and Matthew Rousu (both of Susquehanna University) on "Using Music for Theory-Driven Entrepreneurship Education." Fleck showed a video of Tracy Chapman performing "Fast Car" that included on-screen interpretations (in the form of subtitles) from an entrepreneurial perspective. For example, the problem of lack of startup capital was identified. Rousu explained how he plays songs — with his preference for 
Broadway tunes-before class to warm up the students and introduce the core concepts of the lecture. They discussed other ways to use music in class, touching on copyright and fair use issues.

\section{Competitive Paper: Cross-Campus Entrepreneurship}

"Competitive papers" involved presentations of research in progress as well as short presentations on topics of interest. Nathalie Duval-Couetil (Purdue University) spoke on "A Decade of Cross-Campus Entrepreneurship Education: Revisiting Old Findings and Asking New Questions." She reviewed the history and nature of entrepreneur education, distinguishing educational outcomes from business incubation outcomes. Duval-Couetil asserted that the two outcomes are different, and that only a focus on education provides long-term benefits. She suggested that entrepreneurship "should be the next business administration," meaning that entrepreneurship should become the normal, general, business degree for students who don't otherwise specialize within business education. Yet the metrics for success in entrepreneurship can be difficult to measure. Is it the number of startups on campus, or the average age of entrepreneurs? Duval-Couetil also asked if campus entrepreneurship centers tended to be student-focused. She noted that goals for business development on campus may not be aligned with the needs of students. She gave the example of students providing free labor for startups. Duval-Couetil expressed concerns for fads in entrepreneurship education (lean launch pads, the business model canvas, startup weekends, and makerspaces) as well as the lack of gender and ethnic diversity in many entrepreneurship programs. Many programs seem to privilege students who have bountiful free time to pursue entrepreneurial ideas outside of class. She advocated for development of entrepreneurial ecosystems that better support women, minority students, and students supporting themselves through college. Many in the audience endorsed this idea. While Duval-Couetil asked many important questions without providing many answers, her commentary and recognition of entrepreneurial hype and fads were thoughtful.

\section{Rocket Workshop: Entrepreneurship Across Campus in a Liberal Arts College}

Carol Cirka, Rebecca Jaroff, and Maureen Cumpstone described their faculty-driven model of cross-campus entrepreneurship at Ursinus College, a small liberal-arts college with no business school. The curriculum emphasizes fostering entrepreneurial mindsets and competencies, not creating startups, and faculty incorporating entrepreneurship into their classes receive extra funding. Although creating startups is not a goal of the program, students are encouraged to create projects on campus. Two recent examples include hosting an art show and helping digitize the college archives. Participants at this short workshop were asked to pair up and share notes about crosscampus entrepreneurship promotion at our own campuses and to provide advice for growing the Ursinus program.

\section{Teaching Cases}

Presenters had a short time in which to describe a case they created, including student learning outcomes and discussion topics. The case could be based on history (for example, the race to the 
South Pole) or a contemporary entrepreneur. Lakshmi Balachandra and Donna Stoddard (Babson College) described a case concerning Rahama Wright, a Washington D.C.-based entrepreneur who helps women in West Africa produce and sell shea butter. Babson students watched a video about the project that began as a nonprofit but faced challenges in expanding distribution. The students then discussed the potential change in Wright's organizational model.

Attendees were asked to rank each case on four factors:

- The case will generate interesting discussions for the class.

- The case is timely and focuses on current issues.

- The case describes a provocative/interesting situation.

- The case fosters students' use of their knowledge and skills.

All presented cases are published in the conference proceedings, which are only available to USASBE members.

\section{Developmental Sessions: Feedback on Research in Progress}

Participants in developmental sessions gathered in roundtables to listen to $\mathrm{Ph}$.D. or faculty researchers explain a research agenda and any preliminary findings and provide feedback and suggestions. These sessions proved interesting to the librarians at the conference: we gained insights into how researchers approach a question, and we also provided advice on research sources and strategies.

Yemisi Awotoye, a third-year Ph.D. student from Morgan State University, discussed her proposed research on fear of failure in entrepreneurship and the possible benefit of videotaped intervention to help reduce such fear ("Effect of an Intervention on Fear of Failure in Entrepreneurship"). Awotoye reported that this topic was inspired from an example of using video to reduce anxiety in patients visiting a dentist. We discussed options to measure fear of failure, to determine sources of such fear, and to factor the role of gender and culture.

Jay Janney (University of Dayton) discussed “The Gig Economy, the Allee Effect, and the Long Tail of Liability of Newness." Based on an influential concept paper by Stinchombe ${ }^{1}$, Jannay asks if the concept of "liability of newness" will change with the rise of the gig/freelance economy. He discussed that having competition in an established industry tends to result in industry growth, less financial risk, and increased profits. Jannay led a discussion on how to test this pattern with selfemployed contractors using the existing Bureau of Labor Statistics classification of occupations.

Morgan Clevenger (Wilkes University) summarized "Preliminary Results of a Multi-State Entrepreneurship Communities Research Initiative.” This large research project, focusing on Texas and Pennsylvania, utilized surveys of entrepreneurs, Dun \& Bradstreet company records, and 2010 Census data to examine multiple factors: local leadership, politics, culture, and entrepreneurial support infrastructure. Clevenger's preliminary analysis of the data suggest that educational attainment matters in successfully creating a business, while actual business planning is less formal than business educators might expect. Clevenger also found that entrepreneurs have mixed feelings

\footnotetext{
${ }^{1}$ Stinchcombe, AL. (1965). Organizations and social structure. In James G. March (ed.), Handbook of Organizations, 153-193. Chicago: Rand-McNally.
} 
about the value of local entrepreneurship support centers and services, including those offered by universities.

\section{Competitive Workshop: Teaching Students to Use Authoritative Data}

Librarians Mary Scanlon (Wake Forest University), Diane Campbell (Rider University), and I provided a 75-minute workshop: "Teaching Students to use Authoritative Industry and Market Datasets in Order to Make Informed Decisions in their Business Plans.” We discussed free sources like Economic Census, American Community Survey, and Consumer Expenditure Survey, as well as subscription databases. After introducing each dataset, we led short discussions on how students could apply the data to improve their proposed ventures. While we had set aside time to have the participants draft an active learning assignment with a grading rubric, the faculty in attendance indicated they would rather get additional exposure to data sources. So we instead used the time to demonstrate commercial products like SimplyMap.

\section{Value for Librarians}

On our way back to the airport, I talked to one of the other librarians about the value of the USASBE conference for us. We agreed there was limited value in the conference regarding the dayto-day work of librarians supporting entrepreneurship programs. However, for librarians involved with the more general teaching of entrepreneurship skill sets and mindsets, USASBE provided a rich conference experience. The conference was also very useful to learn more about the teaching and research needs of faculty and Ph.D. students within the academic subfield of small business and entrepreneurship. Finally, we agreed there was much value in librarians engaging with professors on teaching and research and advocating for the roles of librarians in entrepreneurship education. 